\title{
EVALUATING THE CONCEPT OF OWNERSHIP INIRANIAN OIL AND GAS LAW
}

\begin{abstract}
Hossein Jahani*
The aim of this article is to examine the concept of ownership and the right to usage oil and gas due to this concept in Iranian oil and gas law. Due to the very important role of this expensive element in government's commercials, ownership in this sphere of law is such a valuable issue. However, we have a wide range of variety in definition of ownership in legal systems around the world, Iranian law as an instance, defines it in specialized terminology: The right to use, exploit and transfer something in any occasion which is not against the statute's prohibitions (Articles 30 and 31 of Iranian Civil Code). Iranian civil code does not limit the ownership only to substances (Article 29 of Iranian civil code) and includes minerals too. The attitude of host government's ownership and the role of foreign company, Iranian oil and gas law and the effect of different contract types need a precise evaluation on this concept. This article examines the ownership concept in depth in Iranian rules and any conflict with international rules and essential ways in new contracts.
\end{abstract}

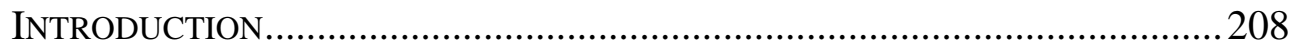

I. INCEPTION OF MINERALS POSSESSION INDEPENDENCE IN IRAN ................209

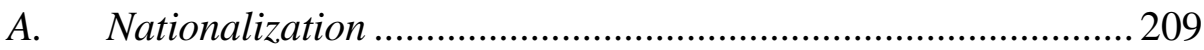

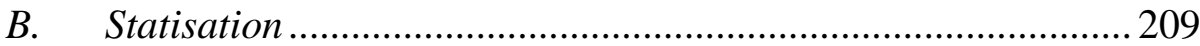

II. FOREIGN GOVERNMENT's RIGHT IN OIL RESOURCES ............................210

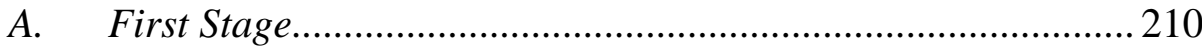

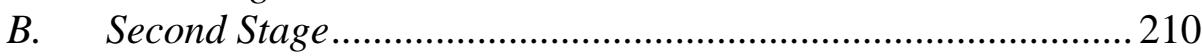

III. BUY BACK CONTRACT .......................................................................210

IV. EXPLORING AND DEVELOPING IRANIAN OILFIELDS THROUGH BUYBACK

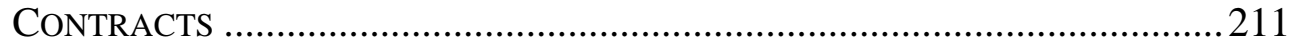

V. OWNERSHIP IN ISLAMIC AND IRANIAN STATUTE ...................................211

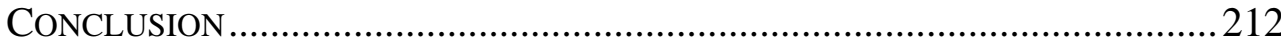

\section{INTRODUCTION}

In most of the world, ownership of valuable minerals is retained by the state. ${ }^{1}$

However, the most important references of oil and gas law are found in governments process in bilateral and multilateral treaties, international conventions, and foreign investments.

\footnotetext{
${ }^{*}$ Ph.D. at law, Tehran applied science faculty professor, Iran. Research fields: Oil and Gas Projects.

${ }^{1}$ S. Lowe, John. Oil AND Gas Law In A NuTShell (Fourth edition 2004).
} 


\section{EVALUATING THE CONCEPT OF OWNERSHIP 209}

Iran as an important exporter of oil and gas, has been tested vast majority of contracts types and can be standing stone of international oil and gas contract process, after Islamic revolution in 1979, Iran's legal system proposed new buyback contract to previous ones. ${ }^{2}$

This article examines the different attitudes of Iranian civil law and international norms and concept of nationalization and statisation and their applicability in oil and gas law.

\section{INCEPTION OF MineRALS POSSESSION INDEPENDENCE IN IRAN}

Inception of minerals possession independence in Iran is identical to nationalization of Iran's oil industry and quit foreign exploiter government's mastership.

An academic definition of nationalization says that:

\section{A. Nationalization}

Nationalization is an important limitation to private ownership, in favor of government's investments.

In other words, nationalization is dispossession private owner of wealth or social and economic activities and transfers it to the nations of a country. It is elimination private capitalization's management to social and economic activities and wealth, and organizes them properly by public management.

\section{B. Statisation}

Statisation system is not identical to nationalization.

Statisation is organizing a national wealth or social and economic activity as a public entity and administrating the entity under the public and governmental law's rules and regulations, vice versa, nationalization is organizing and administrating just like a private entity under the rules and regulations of private law. ${ }^{4}$

We can conclude that nationalization, as professor Tabatabai's definition is by private law regulation, however being under the public management.

Because energy sector in Iran is a valuable instance, and Iranian oil and

\footnotetext{
${ }^{2}$ Mohebbi, 1386 solar.

${ }^{3}$ S. Lowe, John, L. Anderson Owen, E. SMith ERnest \& E. Pierce David, Cases and Materials ON OIL AND GAS LAW (Thomson publication 2004).

${ }^{4}$ Tabatabai Motameni, Manuchehr, Public Freedoms and Human’s Right, at 15, 1390 solar (Tehran University Publication).
} 
gas regulation pursue so-called attitude during the time.

\section{FOREIGN GOVERNMENT’s Right IN OIL RESOURCES}

To study the issue in depth, we need to divide the concept of ownership in oil and gas law, evaluate the nature of foreign company's possession on oil and gas in depository, and divides to two stages:

\section{A. First Stage}

When the oil and gas has not been derived and is still a resource, in this category the nature of foreign investor company's right will be assessed on subterranean resources.

\section{B. Second Stage}

The stage that oil has been discovered and derived as a substance and can be the issue of possession right.

In this category, the nature of this right can be evaluated. ${ }^{5}$

\section{BUY BACK CONTRACT}

The buy back contract - in its simple type-is a bilateral contract, which in the first contract, we have the rights and obligations about selling equipment and technology, whereas, in buyback contract, we have the obligations about selling the substance which has been gotten using socalled equipment and technology.

Two parties of buy back contract are: vendor and customer.

Buy back contract is in fact a service purchase contract. Foreign investor companies in this contract are bound to prepare all the investing project's budget and install technical and equipment engineering process, and transfer it to host government after installation.

In this type of contract, the benefit of stocks would be due to selling the products.

This kind of contract is more usual in countries which have prohibitions in foreign government or private ownership in oil and gas industry.

As we said in nationalization part, Iran is a country with prohibitions in foreign government or private ownership in oil and gas industry, so buying

\footnotetext{
${ }^{5}$ Iranpoor, Farhad, Ownership's Concept in Oil Contracts, 40 LAW JouRnal OF TeHRAn UnIVERsity, 1389 solar.
} 
back contract is a good option to such countries.

Ownership of oilfield and oil and gas its self, in buy back contracts, has been explicitly allocated to host government. ${ }^{6}$

\section{EXPLORING AND DEVELOPING IRANIAN OILFIELDS THROUGH BUYBACK CONTRACTS}

Buyback contracts can be categorized as (risky services) contracts, which are contractor's expenses reimbursement, by allocating a part of production.

Territory, scope of work, expenses, commission and job duration should be mentioned in the contract. ${ }^{7}$

\section{OWNERSHIP IN ISLAMIC AND IRANIAN STATUTE}

Iranian civil code does not limit the scope of ownership to substances.

According to Article 29 of Iranian civil code:

It is possible for people to derive the following rights from property:

1. The right of possession (whether of the substance of the thing orit's benefits).

2. The right of exploitation.

3. Rights of easement in the property of another.

And also in next articles we have:

Article 30-Every owner has unlimited rights of occupation and exploitation over his property in matters in which the law has made an exception.

Article 31-No property can be alienated from the possession its owner except in accordance with a legal order. ${ }^{8}$

Therefore, we can argue that Iranian civil code can include ownership's concept in oil and gas law and oilfields.

Iranian legal system has been affected by Shieefegh (Sharyieh).

Specially, in recent three decades, after Islamic revolution of 1979, this effect has been emphasized in Iranian civil and criminal codes.

As Iranian law, ownership has three symbols, ownership is:

Absolute

Permanent

and Exclusive

\footnotetext{
${ }^{6}$ AUTOPSY IN IRANIAN OIL AND GAS INDUSTRY, at 56, 1380 Solar.

${ }^{7}$ Discovering and Extension of Iranian Oil Fields Due to Buy Back Contracts, Dr. Shiravy \& Dr. Ebrahimi.

${ }^{8}$ IRANIAN Civil CoDe, 1386 Solar (37th publish, Didar publication).
} 
Whereas, Shieefegh (Sharyieh), defines it as:

Any kind of legal mastership would be possession, and ownership is used for so-called possessions.

\section{CONCLUSION}

So in conclusion, we can argue that Iranian legal system in recent decades accepts the buyback contracts as a new method to use foreign company in addition to domestic science and technology, which can improve international relationship. As Iranian civil code and oil and gas regulations are not in conflict with such contracts, furthermore, Shieefegh (Sharyieh) accept elements of so-called possession. 